\title{
THE NATION'S HUMAN CAPITAL IS A MAJOR RESOURCE OF THE STATE'S INNOVATION POTENTIAL
}

\author{
Aleksander Bogashko \\ Pavlo Tychyna Uman State Pedagogical University, Ukraine
}

\begin{abstract}
The problem is important and relevant because in the process of formation of the world economy and economic science, the goals and objectives, means and criteria of modern socio-economic development of countries have been rethought. Studies of competitiveness, priority factors of economic growth, and criteria for the effectiveness of economic activity in a market environment have become relevant. The state of the economy, intensification, progress of economic development depend on innovative potential and human capital, which affect the system of economic relations at the micro, macro and mega levels.

The aim of the article is to study the evolution of the scientific concept of human capital and determine the socio-economic nature of national human capital. The article also determines the value of human capital in the system of factors of innovative development of the economy of countries.

The article used general scientific and special research methods: analysis and synthesis, morphological analysis, logical generalization and comparison, graphical method.

The study presents approaches to determining the socio-economic category of "human capital". An analysis of the scientific literature indicates that the category of "human capital" most fully reflects the role and place of people in the economic system.

The article notes that different countries of the world use different indicators of human capital: the Human Development Index, the Quality of Life Index and the Index of Human Happiness. The most common indicator of human capital development is the Human Development Index. The article presents the author's classification of human capital, which includes the levels and structure of capital. This will help government agencies better regulate the development of national human capital.
\end{abstract}

Keywords: company human capital, human capital, innovative development, innovative potential, intelligence, national human capital, personal human capital.

\section{Introduction}

During the formation of the world economy and economic science, a rethinking of the goals and objectives, means and criteria of socio-economic development took place. In modern conditions of dynamic pace of economic development, globalization and internationalization of economic processes, studies of competitiveness issues, priority factors of economic growth, and criteria for the effectiveness of economic activity in a market environment are

(C) Rēzeknes Tehnologiju akadèmija, 2020

http://dx.doi.org/10.17770/sie2020vol6.5056 
becoming more relevant. The state of the economy, its intensification and progress are determined by the innovative ability of society and the innovative potential of the country. These processes radically alter the system of economic relations both at the micro, macro and mega level.

The aim of the article is to study the theoretical foundations and evolution of the concept of human capital, to determine inextricably linked its socioeconomic nature and role in ensuring the innovative development of the national economy. To realize the main aim of the article, we set the following tasks: to analyze the evolution of the socio-economic category "human capital"; offer a modern interpretation of this concept; propose the author's classification of human capital by level of use and the structure of its types.

The research used general scientific and special methods, in particular: analysis and synthesis - in the classification of human capital by the levels of use and selection of the structure of its species; comparison, systematization and generalization - while clarifying the essential features of the concept of "human capital”, graphical method - to clearly represent the theoretical and practical provisions of the scientific article.

\section{Main text}

Fundamental theoretical and empirical studies of human capital are reflected in the works of such foreign scholars as W. Petty, A. Smith, A. Marshall, J. Mill, E. Denison, G. Kendrick, F. Machlup, P. Mintzer, L. Thurow, I. Fisher and others. T. Schultz and G. Becker became Nobel laureates for the development of the theory of human capital. Modern problems of the formation and development of human capital as a factor in the competitiveness of national economies are actively investigated by such domestic scientists and economists as O.S. Mocherna, A.V. Pereverzieva and others.

It should be noted that the concept of human capital is sufficiently developed, but so far there is no single point of view among scientists regarding the meaningful content of the category "human capital".

The methodological basis of scientific research is a combination of principles, techniques, general theoretical, special and interdisciplinary methods of scientific research. The information base of the research is the works of Ukrainian and foreign scientists on the problems of human capital development, the formation and use of knowledge, and intellectual potential; Internet resources; materials of periodicals and international examinations and other reference sources.

The current state of the world economy is characterized by the development of market relations and production in the conditions of limited (due to their high cost) material resources. The integration of developing countries 
into the global economic space with a high level of competition has led to a transition from a resource-based to an innovative model of economic development. First of all, this is due to the accumulation and effective use of the innovative potential of the economies of some countries.

The study of innovative potential and its definition is associated with the interpretation of the term "potential". In our study, the term potential should be understood as the resources available to economic entities, their optimal structure and the ability to rationally use them to achieve their goals. That is why the definition of innovative potential often differs only in the composition of the resources of innovative activity.

L.H. Melnyk believes that "innovative potential is a combination of financial, material and labor resources that a specific system can use to implement pilot projects that are aimed at the production of new types of products” (Melnyk, 2003).

As a combination of resources of innovative activity and the ability to perceive and introduce innovations, determines the innovative potential of H.M. Huzenko: "The innovative potential of the economy is a combination of factors of innovative economic development: resource, such as resource potential; effective, aimed at realizing the existing possibilities for implementing the modern innovation process; internal, which represent the ability of the economic system to perceive and introduce innovations" (Huzenko \& Babak, 2009).

The Law of Ukraine "On Priority Directions of Innovation in Ukraine" considers innovative potential as a set of scientific, technological, financial, economic, industrial, social, cultural and educational opportunities of a country (industry, region, enterprise, etc.) necessary to ensure innovation development. At the same time, such an activator of potential as an innovative culture (in our study, the innovative ability of society), which characterizes the level of educational, general cultural and socio-psychological preparation of the individual and society as a whole for the perception and creative implementation of the idea of developing a national economy on innovative basis (Law of Ukraine, 2011).

It can be concluded that the basis of innovation potential, its source is the person and society, as representatives of a certain educational and qualification level and moral and psychological qualities necessary for the implementation of successful innovative impact on natural resources, financial flows and production capacity in the process of economic activity. In the future, in the context of globalization and activation of migration processes, countries will compete for quality of life. A high standard of living is capable of forming and developing human capital. In this context, a detailed study of the conditions for the formation and development of human capital as the basis of innovative 
competitiveness at all levels of the national and world economy becomes relevant.

The concept of human capital is based on the achievements of institutional theory, neoclassical theory, neo-Keynesianism, and other economic theories. Its emergence was the answer of economic and related sciences to the demand of the real economy and life. There was a problem of in-depth understanding of the human role and the accumulated results of its intellectual activity on the pace and quality of development of society and economy. The impetus for the creation of the theory of human capital was the statistics of growth of economies of developed countries of the world, which exceeded the calculations based on the account of classical factors of growth (Bogashko, 2017).

The first attempt to evaluate human capital was made by the founder of Western political economy, William Petty. As early as 1683, the outstanding English economist and statistician in the scientific work "Political Arithmetic" revealed the essence of the concept of the economic value of a human worker. However, he did not bring his views to the level of an independent theory (McCormick, 2010). After that, various aspects of human capital were described in the writings of the classics of economic science, in particular A. Smith, K. Marx, A. Marshall.

A. Smith in 1776, in his work "The Wealth of Nations", investigated that the differences between the capabilities of people with different levels of education and training reflect differences in their incomes, and also ranked the knowledge, skills and experience of people, like machines, land, buildings in the fixed capital of society (Smith, 1937).

Particularly noteworthy are the works of K. Marx, who justified the category of "labor" as the main productive force of society, determined its value, and considered the development of physical, mental, creative abilities of a person from the point of view of direct production as a process of creating fixed capital, which requires corresponding costs (Marx, 1999).

A. Marshall did not include man and his natural qualities in the category of capital, since man himself is not a commodity, but he believed that knowledge and ability to work is an integral part of capital (Marshall, 1920).

The concept of "human capital" came into science in the early 60s of the twentieth century. The economists of the Chicago school G. Becker and T. Schultz began to use it in science. Having developed the concept of human capital, they proved that human capital, and not material means of production, is a determining factor in achieving a high level of competitiveness of the national economy. The source of economic growth is education, science, healthcare, which at that time were interpreted exclusively as industries that consume, rather than produce. T. Schultz by "human capital" refers to the knowledge, skills and abilities of a person that contribute to the growth of the productive power of her 
labor (Schultz, 1975). The most important feature of such capital is that a person and his human capital are inseparable from each other. It becomes human capital because it is an integral part of a person and a form of capital, since human knowledge and abilities are a source of future earnings. According to Schulz, from the aggregate product produced in society to the accumulation of human capital, not $1 / 4$ is used, as follows from most theories of reproduction of the 20th century, but $3 / 4$ of its total value. G. Becker, at the same time developing this theory at the micro level, noted that "human capital is formed by investing in people, among which are education, training in production, health care costs, migration and the search for information on prices and incomes” (Becker, 1964). G. Becker praised the cost-effectiveness of education, primarily for the employee himself. Becker also made a special contribution to the theory of competition, strategy and company development. He introduced a distinction between special and general investment in man. He emphasized the special importance of special training, special knowledge and skills. Special training of employees forms the competitive advantages of the company, the characteristic and significant features of its products and market behavior, ultimately, its know-how, image and brand. Firms and corporations themselves are primarily interested in special training, therefore they finance it.

Further thorough research on the main provisions of the concept of human capital was carried out by E. Denison, G. Kendrick, F. Machlup, P. Mintzer, L. Thurow, I. Fisher and others (Kuzminov, Sorokin, \& Froumin, 2019). During this period, Western scholars began to invest much broader content in the concept of "human capital". L. Edvinson and M. Malone regarded this capital as a component of intellectual capital along with structural capital (Edvinsson \& Malone, 1997). Human capital, in their opinion, cannot be the property of the company, unlike structural capital, which consists of technical and software, organizational structure, patents, licenses, trademarks, databases, electronic networks and all that can be an object sale. They call the elements of "human capital” embodied in the company's employees a combination of knowledge, practical skills, creative abilities, as well as moral values of the company, work culture, ability to innovate, company philosophy and general approach to business.

The multifaceted nature of the category of "human capital" focuses both on highlighting one or another characteristic, and on the whole multitude of manifestations of this concept. The main approaches to its determination by foreign and domestic scientists are grouped in the form of table 1. 
Table 1 Systematization of approaches to the definition of socio-economic categories of "human capital" (Mocherna, 2009)

\begin{tabular}{|c|c|c|c|}
\hline No. & Author & Approach & Definition of category \\
\hline 1 & $\begin{array}{l}\text { R. Dornbush, } \\
\text { E. Dolan, } \\
\text { D. Lindsey, } \\
\text { L. Thurow, } \\
\text { I. Fisher }\end{array}$ & $\begin{array}{l}\text { Resource } \\
\text { Consumer }\end{array}$ & $\begin{array}{l}\text { Human capital is the totality of all possible } \\
\text { qualities of workers that determine productivity } \\
\text { and can become sources of income for a person, } \\
\text { family, enterprise }\end{array}$ \\
\hline 2 & $\begin{array}{l}\text { G. Becker, } \\
\text { T. Schultz, } \\
\text { D. Bohynia, } \\
\text { O. Holovin, } \\
\text { O. Hrishnova }\end{array}$ & Investment & $\begin{array}{l}\text { Human capital is an intangible asset that is } \\
\text { formed and accumulated as a result of } \\
\text { investment in education, health care, recreation, } \\
\text { and cultural development }\end{array}$ \\
\hline 3 & $\begin{array}{l}\text { A. Dobrynin, } \\
\text { S. Diatlov, } \\
\text { M. Krytskyi, } \\
\text { I. Ilinskyi }\end{array}$ & $\begin{array}{c}\text { Historical } \\
\text { (Civilization) }\end{array}$ & $\begin{array}{l}\text { Human capital is a form of expression } \\
\text { (organization, functioning, development) of the } \\
\text { productive forces of a person that is adequate to } \\
\text { the post-industrial state of the society of the era } \\
\text { of the scientific and technological revolution, } \\
\text { based on the movement of an economic subject } \\
\text { as a new force of social progress }\end{array}$ \\
\hline 4 & $\begin{array}{l}\text { C.McConnell, } \\
\text { S. Brue } \\
\text { N. Holikova }\end{array}$ & Cumulative & $\begin{array}{l}\text { Human capital is an intangible asset that } \\
\text { accumulates as a result of previous investments } \\
\text { in education, training, healthcare and more }\end{array}$ \\
\hline 5 & $\begin{array}{l}\text { Y. Ben-Porat, } \\
\text { R. Ehnenberg, } \\
\text { A. Smith }\end{array}$ & Personal & $\begin{array}{l}\text { Human capital is an asset owned by workers } \\
\text { (and not their employers) who possess it and } \\
\text { decide when, how and where they will invest it }\end{array}$ \\
\hline 6 & $\begin{array}{l}\text { J. Coleman, } \\
\text { A. Bilyk }\end{array}$ & Psychological & $\begin{array}{l}\text { Human capital arises from a combination of } \\
\text { activity with mental reality, psyche and } \\
\text { motivation }\end{array}$ \\
\hline
\end{tabular}

Source: formed on the basis (Abuzyarova et al., 2019; Mocherna, 2009; Kuzminov et al., 2019).

Thus, human capital is a category that at the present stage most fully reflects scientific views on the role and place of man in the economic system. The basic definition of human capital is the concept of capital as "self-rising value". From these positions, a person gains the functions of capital only when he becomes a subject of economic activity, that is, when he begins to work, and investments make a profit.

In our opinion, human capital is a set of human abilities that are closely related to his activities. One of the most important properties of human capital is that it is in continuous development. A person is able to control his development within the appropriate limits, applying precisely those abilities that are most necessary in this case. Consider the following types of abilities (Kamenetsky \& Patrikeev, 2006): 
- Intellectual, which express a person's ability to analyze and summarize information;

- Labor, among which the prevailing ability to process information on specific issues on which a person has enough knowledge;

- $\quad$ Physical, associated with the implementation of a coordinated impact directly on objects of labor;

- $\quad$ Other abilities associated with the fact that some people have specific qualities to a much greater extent than others.

Human capital in the economic sphere is an assessment of the person's abilities to generate income through the use of intellectual, labor and other abilities, as well as the resources that society controls.

To analyze the conditions for the formation and development of human capital in different countries of the world, various indicators are used: the Human Development Index, the Quality of Life Index and the Index of Human Happiness. The most common indicator that allows you to assess the conditions for the formation and development of human capital is the Human Development Index, which reflects the average level of achievements of the country in the three most important elements of human development: a long and healthy life, which is measured by the indicator of life expectancy at birth; knowledge, measured by the level of adult education and the total number enrolled in educational institutions; a decent standard of living, which is measured by the indicator of Gross Domestic Product per capita.

However, as A.V. Pereverzieva points out in economic literature, the equal sign is often put between the concepts of "human capital" and "human potential". Although these two concepts are similar, this is not true. Although the definition of human capital and human potential is similar, there is a significant difference between them. The concept of human potential is included in the concept of "human capital", since in both cases a person with a certain education, health, upbringing, motivational preferences is considered, but the concept of human capital refers more to economic activity, while human capital is a more sociological and psychological concept (Pereverzieva, 2008).

In a theoretical aspect, the concepts of "human capital" should be distinguished at three levels:

- $\quad$ On a personal level, human capital refers to the knowledge and skills that a person received through education, training, practical experience (using his natural abilities) and thanks to which he can provide valuable production services to other people. At this level, human capital can be compared with other types of personal property, generating income, and it is called personal or private human capital; 
- At the microeconomic level, human capital represents the combined qualifications and professional abilities of all employees of the enterprise, as well as the achievements of the enterprise in the effective organization of labor and personnel development. At this level, human capital is associated with the production and commercial capital of the enterprise, since profit is obtained through the efficient use of all types of capital;

- At the macroeconomic level, human capital includes accumulated investments in such areas of activity as education, vocational training and retraining, career guidance and employment services, rehabilitation, etc., and therefore is an essential part of the country's national wealth. This level includes the entire amount of human capital of all enterprises and all citizens of the state (Filatov \& Vysochina, 2009).

We propose the following structure of human capital, including its classification and division into types (Figure 1), which, in theoretical terms, will help to more fully reveal the essence of this concept, and in practical terms it will provide opportunities for state regulation of its development.

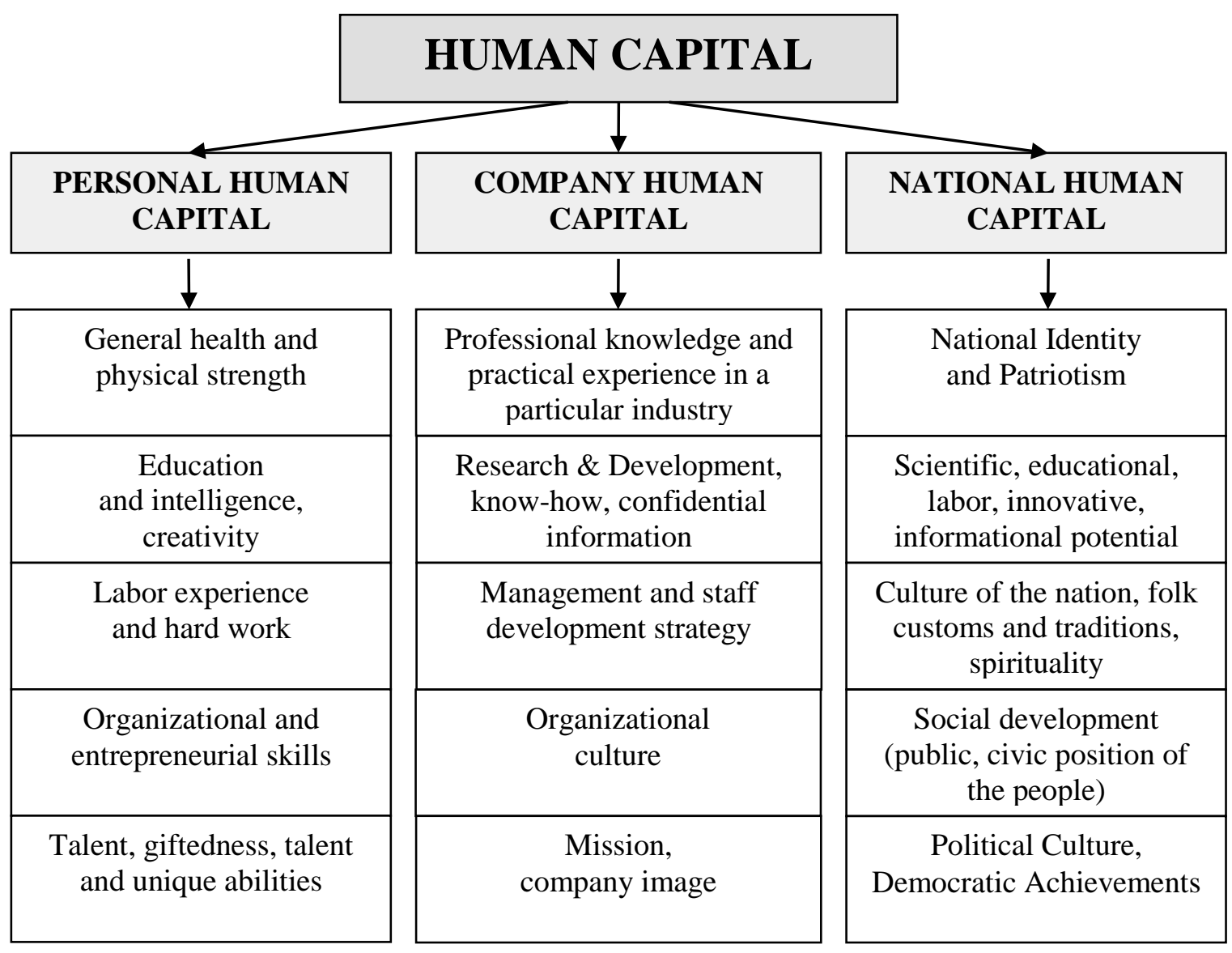

Figure 1 Classification of human capital according to levels use and species structure (classified by the author) 
In our opinion, human capital is a socio-economic category that characterizes the totality of productive individual and social abilities that have developed and developed as a result of investments, such as general health and physical strength, education and level of intelligence, work experience and hard work, organizational and entrepreneurial abilities, talent and talent, which are purposefully used in a particular area of social production, contribute to the growth of labor productivity and agodarya that affect the growth of income both its owner and society or the nation as a whole.

Thus, the article analyzes the evolution of the socio-economic category of "human capital" and on this basis a modern interpretation of this concept is proposed. The classification of human capital by levels of use and the structure of its types is presented, which will provide new opportunities for state regulation of its development.

The development of man as the highest social value, improving the quality of human life is an important priority and one of the factors for the effective economic recovery of the state economy. The main tasks of managing the development of national human capital should be recognized: improving the healthcare system and education, gradually increasing the level of financing for human development, creating favorable conditions for the formation and development of human capital at all levels of the national economy. The sociodemographic policy, which should provide favorable conditions for the reproduction, preservation and enhancement of quantitative indicators and qualitative characteristics of the state's population, has a significant influence on the formation of total human capital.

Subsequent scientific developments in this direction may include research and development of a concept for the development of national human capital and the provision of practical recommendations for its implementation.

\section{References}

Abuzyarova, D., Belousova, V., Krayushkina, Zh., Lonshcikova, Y., Nikiforova, E., \& Chichkanov, N. (2019). The Role of Human Capital in Science, Technology and Innovation. Foresight and STI Governance, 13(2), 107-119. DOI: 10.17323/25002597.2019.2.107.119

Becker, G.S. (1964). Human Capital: A Theoretical and Empirical Analysis with Special Reference to Education. Chicago: University of Chicago Press. Retrieved from https://www.nber.org/books/beck94-1

Bogashko, A.L. (2017). The importance of innovative activity of society in the evolution process of the world economic system. Economies' Horizons, 2(3), 4-8. Retrieved from http://nbuv.gov.ua/UJRN/fineconsm_2017_2_3

Edvinsson, L. (1997). Developing Intellectual Capital at Skandia. Long Range Planning. Elsevier Ltd, 30(3), 366-373. DOI: http://dx.doi.org/10.1016/S0024-6301(97)90248-X

Edvinsson, L., \& Malone, M. (1997). Intellectual Capital. Harper Business, New York. 
Filatov, V.M., \& Vysochina, L.V. (2009). The importance of human capital in providing innovative development of Ukraine. Business Inform, 12(2), 92-94.

Huzenko, H.M., \& Babak, V.V. (2009). Innovative potential of the national economy and the role of the state in its reproduction in Ukraine. Business Inform, 11(2), 41-42.

Kamenetsky, V.A., \& Patrikeev, V.P. (2006). Capital (from simple to complex). Moscow: Economics.

Kuzminov, Y., Sorokin, P., \& Froumin, I. (2019). Generic and Specific Skills as Components of Human Capital: New Challenges for Education Theory and Practice. Foresight and STI Governance, 13(2), 19-41. DOI: 10.17323/2500-2597.2019.2.19.41.

Marshall, A. (1920). Principles of Economics (Revised ed.). London: Macmillan; reprinted by Prometheus Books. Retrieved from http://www.library.fa.ru/files/MarshallPrinciples.pdf

Marx, K. (1999). Capital. A Critique of Political Economy. Moscow: Progress Publishers. Retrieved from https://www.marxists.org/archive/marx/works/download/pdf/CapitalVolume-I.pdf

McCormick, T. (2010). William Petty: And the Ambitions of Political Arithmetic. Oxford: Oxford Univ. Press. DOI:10.1093/acprof:oso/9780199547890.001.0001

Melnyk, L.H. (2003). Information Economics: Textbook. Sumy: ITD “University Book”.

Mocherna, O.S. (2009). Dialectics of the concept of human capital in the conditions of transnationalization. Business Navigator, 1, 27-38.

Pereverzieva, A.V. (2008). Stages of formation of human capital. Bulletin of the Donetsk National University of Economics and Trade named after Mikhail Tugan-Baranovsky, 3, 66-84.

Pro priorytetni napriamy innovatsiinoi diialnosti v Ukraini. Zakon Ukrainy vid 08.09.2011 no. 3715-VI. Verkhovna Rada Ukrainy. Zakonodavstvo Ukrainy [On Priority Areas of Innovation Activity in Ukraine. Law of Ukraine 09/08/2011 no. 3715-VI / Legislation of Ukraine]. Retrieved from http://zakon2.rada.gov.ua/laws/show/3715-17

Schultz, T.P. (1975). Human capital: Policy Issues and Research Opportunities. Human Resources. Fiftieth Anniversary Colloquium VI, 1-84. Retrieved from https://www.nber.org/chapters/c4126

Smith, A. (1937). The Wealth of Nations. New York: Random House, Inc. Retrieved from https://www.marxists.org/reference/archive/smith-adam/works/wealth-ofnations/index.htm 